\title{
WEED SEEDBANK DYNAMICS IN MAIZE UNDER DIFFERENT HERBICIDE REGIMES
}

\author{
A. RAHMAN, T.K. JAMES, J.M. MELLSOP and N. GRBAVAC ${ }^{1}$ \\ AgResearch, Ruakura Research Centre, Private Bag 3123, Hamilton, \\ New Zealand \\ ${ }^{1}$ AgriQuality National Seed Laboratory, PO Box 609, Palmerston North, \\ New Zealand \\ Corresponding author: anis.rahman@agresearch.co.nz
}

\begin{abstract}
The influence of different herbicide regimes on the size and composition of the soil weed seedbank in maize was studied over three years. Preemergence atrazine, alachlor, atrazine + alachlor or no herbicide treatments were imposed on the same plots each year. Soil samples to $100 \mathrm{~mm}$ depth were collected each autumn and spring and the seedbank was estimated by seed extraction and seedling emergence. Data showed strong positive correlation between the two methods. Soil seedbank increased dramatically by each autumn but declined by spring. The total seedbank increased over three years in the no herbicide treatment. Good weed control by atrazine + alachlor kept seedbank density at low levels. However seed numbers increased, particularly in the first two years, with only partial weed control using atrazine or alachlor singly. A sharp increase of fathen (Chenopodium album) seeds illustrated the danger of building seedbanks of weeds which become tolerant to the strategies used.

Keywords: weed seedbank, weed emergence, seed extraction, herbicide regimes.
\end{abstract}

\section{INTRODUCTION}

One of the major factors affecting annual weed populations is the large and potentially transient soil seedbank (Dekker 1999; Forcella et al. 1996). Carry-over of viable seeds in the soil from previous years can buffer the effects of weed control and hence maintain the weed problem (Mayor \& Dessaint 1998). The large and heterogeneous seed rain from mature weed communities adds to those of previous years to determine the new seedbank composition. Weed seed production can be reduced by management factors, but even a few weed escapes can produce enough seed to partly replenish weed seedbanks (Hartzler 1996). Elimination of weed seed production for a few years can lead to the incorporation of fewer weed seeds into the seedbank (Burnside et al. 1986; Schweizer \& Zimdahl 1984).

Herbicides reduce weed densities and hence reduce the number of weed seeds that are produced and enter the seedbank (Barberi et al. 1998). Although herbicides are effective in controlling weeds, increasing environmental awareness and evolution of resistance has created a desire to reduce the amount of herbicides applied to arable fields. However, reduced herbicide inputs may lead to increased weed escapes and weed seed production, which may in turn magnify crop management problems in future years. Establishing the extent to which the dynamics of future weed seedbanks is influenced by the current level and frequency of weed control is becoming increasingly important.

The objective of this study was to determine the influence of different herbicide regimes in maize on the size and composition of the weed seedbank over a 3-year period. Such information will be useful for making decisions based on risks, costs and benefits. 


\section{MATERIALS AND METHODS}

This study was set up in spring 1995 and was continued over three growing seasons at Rukuhia near Hamilton. The soil is a Hamilton clay loam of volcanic origin $(55 \%$ sand, $18 \%$ silt, $27 \%$ clay, $3.1 \%$ organic carbon and a $\mathrm{pH}$ of 5.3 ) and the site had been under continuous maize cropping for over 10 years. The trial site remained undisturbed after the previous maize crop was harvested in 1995 . It was rotary hoed to $15 \mathrm{~cm}$ depth in early October and the final cultivation was done with a rototiller before planting. A similar cultivation regime was carried out in each of the subsequent years.

Maize (Zea mays cv. Pioneer 3527) was planted in late October/early November each year using a Nodet Gougis precision vacuum planter at a population of 102,600 seeds/ha. Planting dates for different years are given in Table 1. The herbicides were applied within 2 days after planting with a $\mathrm{CO}_{2}$ powered backpack sprayer fitted with TeeJet 11004 TTVP nozzles, at $210 \mathrm{kPa}$. The treatments included atrazine (Gesaprim $500 \mathrm{FW})$ at $1.5 \mathrm{~kg} / \mathrm{ha}$, alachlor (Lasso Micro-Tech) at $3.3 \mathrm{~kg} / \mathrm{ha}$, atrazine $1.5 \mathrm{~kg} / \mathrm{ha}+$ alachlor $3.3 \mathrm{~kg} / \mathrm{ha}$, and no herbicide. Individual plots were $6 \mathrm{~m} \times 10 \mathrm{~m}$ containing eight crop rows at a row spacing of $75 \mathrm{~cm}$. The treatments were replicated four times in a randomised block design. The maize crop was harvested each year in early May.

\section{Soil sampling}

Soil samples for enumeration of the weed seedbank were taken soon after planting the crop in spring 1995. Thereafter samples were collected every autumn (May) and spring (September/October) for three years (Table 1). Each sample, consisting of nine cores from each plot, was taken with a $75 \mathrm{~mm}$ diameter soil corer, set for $100 \mathrm{~mm}$ depth. All soil samples were placed into separate plastic bags and returned to the laboratory for processing.

TABLE 1: Details of planting, spraying and soil sampling dates.

\begin{tabular}{cccc}
\hline Year & Planting & Spraying & Soil sampling \\
\hline $1995 / 96$ & 31.10 .95 & 1.11 .95 & 3.11 .95 \\
& & & 28.5 .96 \\
$1996 / 97$ & 30.10 .96 & 1.11 .96 & 9.10 .96 \\
& & & 6.5 .97 \\
$1997 / 98$ & 5.11 .97 & 7.11 .97 & 22.9 .97 \\
& & & 31.5 .98 \\
& & & 7.9 .98 \\
\hline
\end{tabular}

\section{Seed enumeration and seedling emergence counts}

In the laboratory the samples were mixed thoroughly while still field moist, passed through a $4 \mathrm{~mm}$ sieve and then subsampled with a riffle sampler. From each sample $2 \mathrm{~kg}$ of moist soil was used immediately for enumeration by the seedling emergence method and the rest was oven dried at $60^{\circ} \mathrm{C}$ for $12 \mathrm{~h}$. From this, $0.5 \mathrm{~kg}$ of soil was sent to the New Zealand National Seed Laboratory, Palmerston North for extraction and quantification of weed seeds. The two enumeration methods for determining viable seed (i.e. seedling emergence and seed extraction) have been described in detail previously (Rahman et al. 1995).

Weed emergence counts were also made in the field plots during the last growing season by protecting the soil during spraying with a $1 \mathrm{~m} \times 1 \mathrm{~m}$ polythene sheet, and counting emerged weeds later. The first weed count was made on 10 December 1997, about 5 weeks after planting and spraying, when the weed seedlings were large enough to identify. The second count was made on 6 January 1998, about 2 months after planting. After each count the seedlings were removed by hand.

All seed counts were adjusted to give the number $/ \mathrm{kg}$ of dry soil. Before analysis of 
variance, all data were transformed to $\log _{10}(x+1)$ to allow for samples where individual weed species were not present.

\section{RESULTS AND DISCUSSION}

During the three years of the study, potentially viable seeds of 36 species were recorded by the seed extraction method in quantities ranging from 1 - 3820/kg dry soil (based on the $500 \mathrm{~g}$ sample). The seedling emergence method, in the total of five incubations, found 43 different weed species in numbers ranging from $1-4120 / \mathrm{kg}$ dry soil (based on the $2 \mathrm{~kg}$ sample). However, for many of the species found by both methods, the quantities were too small to analyse. The most common and abundant weed species encountered were divided into three groups. The first group (summer grasses) included smooth witchgrass (Panicum dichotomiflorum), summer grass (Digitaria sanguinalis), barnyard grass (Echinochloa crusgalli) and crowfoot grass (Eleusine indica). The second group comprised summer broadleaf weeds including willow weed (Polygonum persicaria), black nightshade (Solanum nigrum), Amaranthus spp. and sow thistle (Sonchus arvensis). The third group consisted of winter broadleaf weeds such as twin cress (Coronopus didymus), spurrey (Spergula arvensis), staggerweed (Stachys arvensis), fumitory (Fumaria officinalis) and speedwell (Veronica spp.). Fathen (Chenopodium album) was also a major summer broadleaf weed present in all plots. However, fathen data are presented separately because the herbicides used did not control it well, and its numbers became very large over the duration of the trial.

Comparison of methods for weed seedbank estimation

Seed numbers counted in the laboratory and seedling numbers emerged in the glasshouse trays were strongly correlated (Fig. 1) with $\mathrm{r}^{2}$ values of $0.93,0.97$ and 0.97 for summer grasses, summer broadleaf weeds and fathen respectively. For winter broadleaf weeds the $\mathrm{r}^{2}$ value was only 0.75 , as a result of smaller and more variable numbers of seedlings germinating in the trays. This could be due to the less favourable growing conditions for winter weeds in the glasshouse (Hartley \& Rahman 1995; Rahman

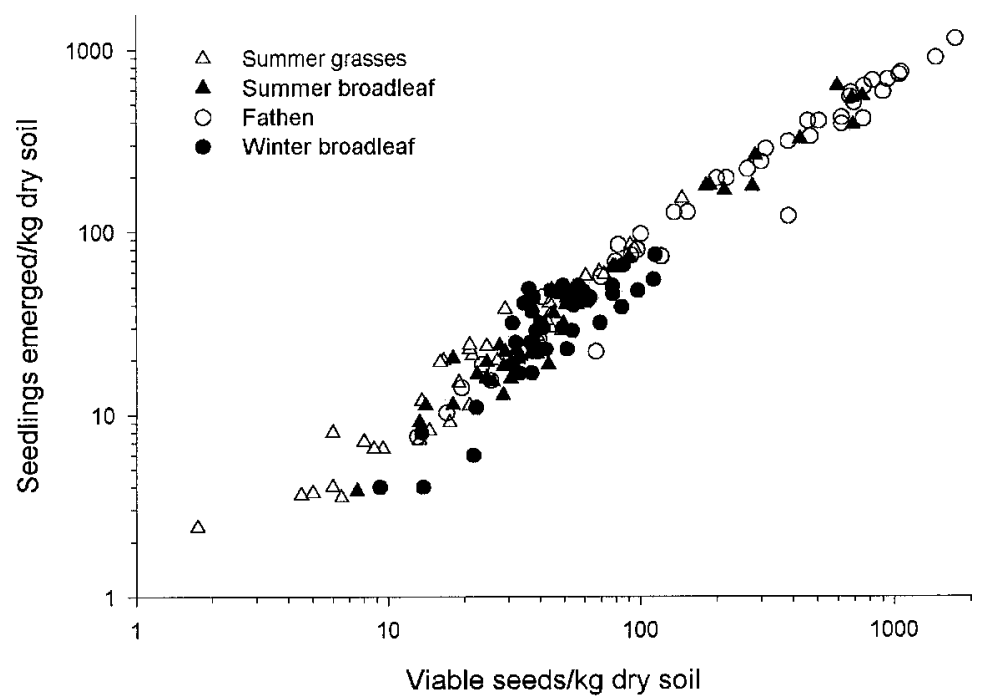

FIGURE 1: Relationship between the number of viable seeds counted in the laboratory and the number of seedlings counted in the trays in glasshouse. The data are from the four treatments at each of the seven sampling dates 
et al. 1995). These high correlation values confirm the results of our earlier studies (Rahman et al. 1998) and demonstrate that either method can be used for estimating the weed seed content of the soil. Because of the strong relationship, only data on seed enumerations from the laboratory are presented here.

\section{Total weed seedbank}

Changes in the total weed seedbank density under different herbicide regimes over the 3-year period are shown in Fig. 2a. Regardless of the treatment imposed, the seedbank was largest in autumn each year, with natural depletion reducing numbers in all treatments by spring. Soil sampling in the spring was done before cultivation (Table 1), so the reduction in weed seed numbers was due to natural losses and not due to cultivation. It would appear, therefore, that up to half of the viable weed seed could be lost over the winter months through natural processes. The active seedbank density in the spring is of greater practical significance, being the reservoir for the weed infestation in the new crop. In the first year seed numbers in the no herbicide treatment were significantly higher than the other treatments. In subsequent years weed seed numbers also increased significantly $(\mathrm{P}<0.05)$ in the single herbicide treatments, but generally were still significantly lower than the no herbicide plots. In the final year fathen seed contributed strongly to the seed numbers in the alachlor treatment as alachlor controlled the grasses and suppressed most broadleaf weeds, allowing rampant growth of fathen.

The effective weed control in plots treated with atrazine + alachlor resulted in lower seed numbers throughout the study. In this treatment seed numbers increased slightly in the third year (Fig. 2a), due to increases in fathen seed numbers (Fig. 2b). These results confirm those of Schweizer \& Zimdahl (1984) and Barberi et al. (1998) who observed that only maize management systems that relied upon continuous effective herbicide applications were able to keep the total weed seedbank size at a low level. Vencill \& Banks (1994) also found that high herbicide inputs were necessary to limit weed seedbank size in grain sorghum (Sorghum bicolor), irrespective of the tillage system used.

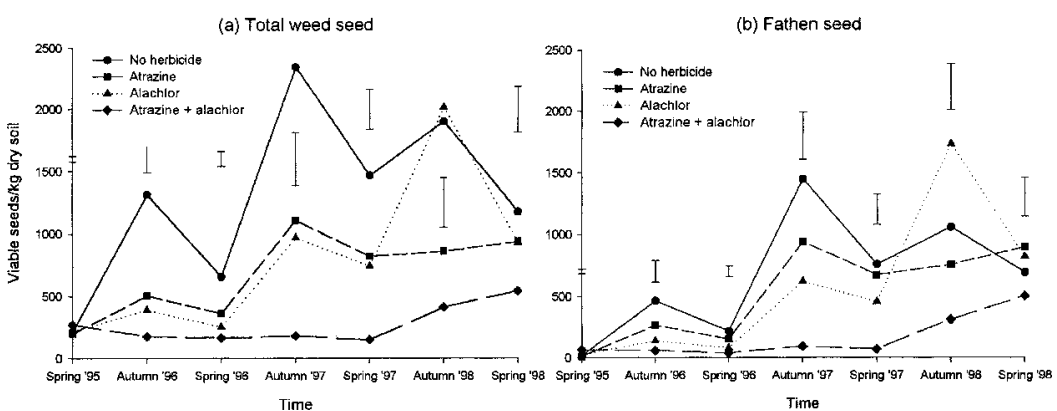

FIGURE 2: Total number of (a) viable weed seeds and (b) fathen seeds in soil samples collected at different times from plots subjected to different herbicide regimes for three years. Error bars represent LSD $(\mathbf{P}<0.05)$.

\section{Seedbanks of individual weed groups}

Numbers of seeds of individual weed groups were mostly in line with the level of control of the specific weeds by the herbicide regime used. Thus atrazine, which does not control the summer grasses, had the highest density of grass weed seeds, even compared to the no herbicide treatment (Fig. 3a). Similarly, the alachlor treatment markedly reduced the seed numbers of summer grasses. Differences between treatments became less obvious with time as the number of grass weed seeds in the seedbank declined steadily in all treatments, probably due to build-up of fathen (which germinates earlier) and the resulting competition in later years. 
The seed density of summer broadleaf weeds (excluding fathen) did not increase over the three year period in plots treated with atrazine or atrazine + alachlor (Fig. 3b). In the alachlor treatment there was some build-up of seed numbers due to poor control of broadleaf weeds by this herbicide. In the absence of any herbicide, there was a steady and substantial increase in summer broadleaf weed seed density. Seed numbers of fathen increased in all treatments during the trial period (Fig. 2b). The increase peaked in the second year for the no herbicide and atrazine treatments and in the third year for the alachlor and alachlor + atrazine treatments. This illustrates that even the continuous use of a normally effective herbicide regime could lead to the rapid build-up of a troublesome weed seedbank by shifting the balance of the weed spectrum to tolerant or sometimes resistant weed species.

Winter broadleaf weeds constituted only about $8 \%$ of the total weed seedbank and their numbers changed only slightly over the duration of the trial (data not presented).

Weed populations in field plots

The weed emergence counts in field plots protected from the herbicide treatments during the last growing season showed a total population of 5238 seedlings $/ \mathrm{m}^{2}$ (in two
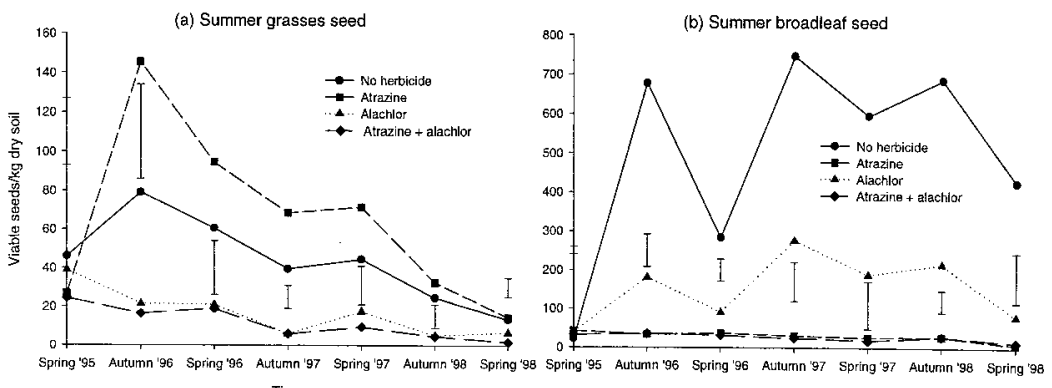

Time

FIGURE 3: Number of viable seeds of (a) summer grasses and (b) summer broadleaf weeds in soil samples collected at different times from plots subjected to different herbicide regimes for three years. Error bars represent LSD $(\mathbf{P}<\mathbf{0 . 0 5})$.

counts) in the no herbicide treatment. The corresponding numbers and proportions for summer grasses, summer broadleaf, winter broadleaf and fathen were $238(4.5 \%), 1820$ $(34.7 \%), 365(6.9 \%)$ and $2786(52.1 \%)$ respectively. The proportions of seedlings of different weed groups were similar to that recorded for seed in the soil seedbanks (5.4, $20.9,7.9$ and $66.9 \%$ respectively).

From the weed population data we have calculated the percentage of the total seedbank (Fig. 2a) that emerged in different treatments. This gave figures of 5.1, 5.9, 7.8 and $15.4 \%$ for the no herbicide, alachlor, atrazine and the atrazine + alachlor treatments, respectively. This shows that the highest percentage emergence of seedlings occurred in the treatment with the lowest seedbank density, whereas the no herbicide treatment (with highest seedbank numbers) had the lowest percentage of the seedbank translating into weed seedlings. This probably is a reflection of the interplant competition which regulates the percentage of weed seedbank likely to emerge in the field.

Results of this study show that in the absence of any weed control, the total soil weed seedbank increased considerably over the three-year period. Adequate control of both grass and broadleaf weeds kept the seedbank density at low levels throughout the study. However, total seed numbers in the soil increased markedly when only partial weed control was achieved in the crop. Use of a specific grass or broadleaf herbicide significantly reduced the seed numbers of weeds that were controlled effectively but the seed density of weeds not controlled increased in the soil, particularly in the first two 
years. Thus, reduced herbicide use in cropping systems is likely to result in a build-up of weed seeds in the soil. Continuous effective weed control is essential to keep the weed seedbank at a low level, which would be desirable for many crop rotations, including pasture. Even with the use of effective strategies there is always a possibility of marked increases in the seedbank of specific weeds that become tolerant or resistant to the management system employed.

\section{REFERENCES}

Barberi, P.; Cozzani, A.; Macehia, M.; Bonari, E. 1998: Size and composition of the weed seedbank under different management systems for continuous maize cropping. Weed Res. 38: 319-334.

Burnside, O.C.; Moonaw, R.S.; Roeth, F.W.; Wicks, G.A.; Wilson, R.G. 1986: Weed seed demise in soil in weed-free corn (Zea mays) production across Nebraska. Weed Sci. 34: 248-251.

Dekker, J. 1999: Soil weed seed banks and weed management. In: Buhler, D.D. ed. Expanding the Context of Weed Management. Food Products Press, New York. Pp. 139-166.

Forcella, F.; Durgan, B.R.; Buhler, D.D. 1996: Management of weed seedbanks. Proc. $2^{\text {nd }}$ Int. Weed Control Congress: 21-26.

Hartley, M.J.; Rahman, A. 1995: Effect of varying glasshouse and soil conditions on weed seed emergence from soil. Proc. 48 ${ }^{\text {th }}$ N.Z. Plant Prot. Conf:: 181-185.

Hartzler, R.G. 1996: Velvetleaf (Abutilon theophrasti) population dynamics following a single years' seed rain. Weed Technol. 10: 581-586.

Mayor, J.P.; Dessaint, F. 1998: Influence of weed management strategies on soil seedbank diversity. Weed Res. 38: 95-105.

Rahman, A.; James, T.K.; Grbavac, N.; Mellsop, J.M. 1995: Evaluation of two methods for enumerating the soil weed seedbank. Proc. $48^{\text {th }}$ N.Z. Plant Prot. Conf:: 175180.

Rahman, A.; James, T.K.; Bourdôt, G.; Grbavac, N. 1998: Weed seedbank estimation, spatial distribution, decline and potential for predicting future weed populations. Plant Prot. Quart. 13(3): 117 -122.

Schweizer, E.E.; Zimdahl, R.L. 1984: Weed seed decline in irrigated soil after six years of continuous corn (Zea mays) and herbicides. Weed Sci. 32: 76-83.

Vencill, W.K.; Banks, P.A. 1994: Effects of tillage systems and weed management on weed populations in grain sorghum (Sorghum bicolor). Weed Sci. 42: 541-542. 